\title{
Anxiety and depression among patients with chronic obstructive pulmonary disease and general population in rural Nepal
}

\author{
Niresh Thapa ${ }^{1,2^{*}}$ (D), Muna Maharjan ${ }^{3}$, Tirtha Man Shrestha ${ }^{4}$, Srijana Gauchan ${ }^{5}$, Prakash Pun ${ }^{6}$ and \\ Yam Bahadur Thapa ${ }^{7}$
}

\begin{abstract}
Background: Anxiety and depression are usually under diagnosed among the patients with Chronic Obstructive Pulmonary Disease (COPD), which has a negative impact on patient quality of life through restriction of activities, loss of independence, and decreased social functioning. The purpose of this study was to describe the levels and characteristics of anxiety and depression in patients with COPD in Nepal as compared to the general population.

Methods: A hospital-based observational comparative analytical study was conducted in the United Mission Hospital, Tansen and the Okhaldhunga Community Hospital, Okhaldhunga, Nepal from June 1st 2015 to April 15th 2016. A convenience sample of two groups of participants were recruited: patients with COPD (study group) and visitors to the facility (comparison group). Anxiety and depression were measured with the Beck Anxiety and Depression Inventory Scale.

Results: A total of 198 individuals participated in the study; 93 with COPD and 105 from the general population. The mean age of the respondents was $58.24 \pm 12.04$ (40-82) years. The mean scores for anxiety and depression in COPD group were $23.76 \pm 9.51$ and $27.72 \pm 9.37$ respectively, while in comparison group, the mean score for anxiety was $8.01 \pm 6.83$ and depression was $11.60 \pm 8.42$. Both anxiety and depression scores were statistically significant between the groups with $p$ value $<0.001$.

Conclusions: Anxiety and depression were almost three times more common in COPD patients compared to the participants from the general population. Early assessment and multi-model treatment of anxiety and depression should be part of management in COPD.
\end{abstract}

Keywords: Chronic obstructive pulmonary disease, Anxiety, Depression

\section{Background}

COPD is characterized by usually slowly progressive and persistent air flow limitation condition which is a common preventable and treatable disease. Tobacco smoking, noxious particles or gases are often associated with an enhanced chronic inflammatory response in the airways and the lung (Global Initiative for Chronic Obstructive Lung Disease, GOLD) [1]. More than 16 million persons in the United States are affected by COPD and it is the fourth

\footnotetext{
* Correspondence: drnthapa@gmail.com

'Department of Gynecological Oncology, Second Clinical College of Wuhan University, Zhongnan Hospital, Wuhan, Hubei, China

${ }^{2}$ Department of General Practice and Emergency Medicine, Karnali Academy of Health Sciences, Jumla, Nepal

Full list of author information is available at the end of the article
}

leading cause of death in world, which will rise to the third most common cause of death worldwide by 2020 . It is one of the important public health issue $[2,3]$.

There is a high prevalence of COPD with an estimated 1.5 to 2 million asthmatics out of total 26 million populations in Nepal. Many patients in Nepal with COPD are illiterate and come from a poor economic status $[2,4,5]$.

Health-related quality of life may have a major impact on COPD patients. They may have restriction of activities, decreased social functioning and loss of independence [6]. COPD has multiple co-morbidities. Anxiety and depression are two of the most common and least-treated comorbidities among COPD patients $[7,8]$. However, only a 
few prospective studies have addressed how to diagnose and manage these disorders and determine their impact on health status among patients with COPD[9].

A study conducted in Nepal by Risal et al., reported, "crude prevalence of anxiety was $22.7 \%$ and of depression $11.7 \%$. The age and gender -adjusted prevalence of hospital anxiety and depression scale (HADS) for anxiety was $16.1 \%$ and for depression 4.2\%" [10].

COPD associated death rate has doubled in the past 30 years, which indicates the healthcare system's failure to address this problem. Increased mortality, decreased functional status, and decreased quality of life in these patients have been linked to psychiatric co-morbidities, particularly anxiety and depression [11].

Few studies were found worldwide on COPD associated with psychiatric co-morbidities and far less in Nepal. Depression and anxiety have been found to negatively affect COPD treatment, including pulmonary rehabilitation. This study compared the levels and characteristics of anxiety and depression in patients with COPD and the general population in rural Nepal.

Table 1 Socio-demographic and clinical characteristics of respondents

\begin{tabular}{|c|c|c|c|}
\hline Characteristics & Study population $(N=198)$ & $\begin{array}{l}\text { COPD group } \\
(N=93)\end{array}$ & $\begin{array}{l}\text { Control group } \\
(N=105)\end{array}$ \\
\hline $\begin{array}{l}\text { Age (mean age } \pm \text { SD) } \\
\quad(\text { Min-Max) }\end{array}$ & $\begin{array}{l}58.01 \pm 12.11 \\
(40-82)\end{array}$ & $\begin{array}{l}64.93 \pm 9.19 \\
(40-82)\end{array}$ & $\begin{array}{l}51.86 \pm 11.06 \\
(40-76)\end{array}$ \\
\hline \multicolumn{4}{|l|}{ Sex } \\
\hline Male & $119(60.1 \%)$ & $41(44.1 \%)$ & $78(74.3 \%)$ \\
\hline Female & 79 (39.9\%) & $52(55.9 \%)$ & $27(25.7 \%)$ \\
\hline \multicolumn{4}{|l|}{ Occupation } \\
\hline Farmer & 107 (54\%) & $47(50.5 \%)$ & $60(57.1 \%)$ \\
\hline Home maker & $46(23.2 \%)$ & $31(33.3 \%)$ & $15(14.3 \%)$ \\
\hline Retired from service & $22(11.1 \%)$ & $12(12.9 \%)$ & $10(9.5 \%)$ \\
\hline Service holder & $12(6.1 \%)$ & $0(0 \%)$ & $12(11.4 \%)$ \\
\hline Labor & $9(4.5 \%)$ & $3(3.2 \%)$ & $6(5.7 \%)$ \\
\hline Business & $2(1.0 \%)$ & $0(0 \%)$ & $2(1.9 \%)$ \\
\hline \multicolumn{4}{|l|}{ Marital status } \\
\hline Married & $166(83.8 \%)$ & $74(79.6 \%)$ & $92(87.6 \%)$ \\
\hline Widow & $24(12.1 \%)$ & 19 (20.5\%) & $5(4.8 \%)$ \\
\hline Separated & $5(2.5 \%)$ & $0(0 \%)$ & $5(4.8 \%)$ \\
\hline Single & $3(1.5 \%)$ & $0(0 \%)$ & $3(2.9 \%)$ \\
\hline \multicolumn{4}{|l|}{ Family type } \\
\hline Joint & $158(79.8 \%)$ & $80(86.0 \%)$ & $78(74.3 \%)$ \\
\hline Nuclear & $40(20.2 \%)$ & $13(14.0 \%)$ & $27(25.7 \%)$ \\
\hline \multicolumn{4}{|l|}{ Education } \\
\hline Illiterate & $120(60.6 \%)$ & $76(81.7 \%)$ & $44(41.9 \%)$ \\
\hline Informal education & $24(12.1 \%)$ & $4(4.3 \%)$ & $20(19.0 \%)$ \\
\hline Primary level & $32(16.2 \%)$ & $10(10.8 \%)$ & $22(21.0 \%)$ \\
\hline Secondary level & $22(11.1 \%)$ & $3(3.2 \%)$ & 19 (18.1\%) \\
\hline \multicolumn{4}{|l|}{ Smoking status } \\
\hline Smoker & $133(67.2 \%)$ & $89(95.7 \%)$ & $44(41.9 \%)$ \\
\hline Non smoker & $65(32.8 \%)$ & $4(4.3 \%)$ & $61(58.1 \%)$ \\
\hline Alcohol consumption & 77 (38.9\%) & $29(31.2 \%)$ & $48(45.7 \%)$ \\
\hline Disease duration (mean year \pm SD) & & $6.75 \pm 5.89$ & \\
\hline Hospitalization in last one year & & $1.88 \pm 0.99$ & \\
\hline $\mathrm{BAl}$, mean $\pm \mathrm{SD}(\text { range } 0-45)^{*}$ & $15.41 \pm 11.35$ & $23.76 \pm 9.51$ & $8.01 \pm 6.83$ \\
\hline $\mathrm{BDI}$, mean $\pm \mathrm{SD}(\text { range } 1-48)^{*}$ & $19.18 \pm 11.97$ & $27.72 \pm 9.37$ & $11.60 \pm 8.42$ \\
\hline
\end{tabular}

${ }^{*}$ Chi square test value: $P$ value $<0.05$ 
Table 2 Beck Anxiety Inventory Score Level among the Respondents

\begin{tabular}{|c|c|c|c|c|c|c|}
\hline \multirow[t]{2}{*}{ Group } & \multicolumn{5}{|l|}{ Anxiety Scale } & \multirow[t]{2}{*}{$P$ value* $\left(X^{2}\right.$} \\
\hline & Minimal anxiety & Mild anxiety & $\begin{array}{l}\text { Moderate } \\
\text { anxiety }\end{array}$ & $\begin{array}{l}\text { Severe } \\
\text { anxiety }\end{array}$ & Total & \\
\hline COPD & $4(4.3 \%)$ & $13(14.0 \%)$ & 39 (41.9\%) & 37 (39.8\%) & $93(100 \%)$ & $<0.001$ \\
\hline Control & 59 (56.2\%) & 32 (30.5\%) & $11(10.5 \%)$ & $3(2.9 \%)$ & 105 (100\%) & \\
\hline Total & $63(31.8 \%)$ & $45(22.7 \%)$ & $50(25.3 \%)$ & 40 (20.2\%) & 198 (100\%) & \\
\hline
\end{tabular}

${ }^{*}$ Chi square value

\section{Methods}

An observational comparative analytical cohort study was conducted in the United Mission Hospital, Tansen and Okhaldhunga Community Hospital, Okhaldhunga, from June 1st 2015 to April 15th 2016. A total of 198 respondents, study group $(N=93)$ and comparison group $(N=105)$, who gave consent were included in the study. The inclusion criteria of respondents for study group were patients age above 40 years, with post bronchodilator, ratio of forced expiratory volume in $1 \mathrm{~s}$ and forced vital capacity (FEV1/FVC) $<70 \%$ and Beta2-agonist reversibility $<15 \%$ (GOLD criteria for the diagnosis of COPD) [1], history of smoking, admitted COPD patients and for comparison group patient visitor visiting in United Mission Hospital, Palpa and Okhaldhunga Community Hospital, Okhaldhunga. The exclusion criteria included unwilling to participate in the study, patient having other co-morbidities which included known psychiatric disorders patient, and other significant respiratory or inflammatory disease: asthma, pulmonary tuberculosis, congestive cardiac failure, interstitial lung disease and taking medicines like Beta- blockers and antipsychotics.

\section{Data collection}

Permission was taken from The General Practice and Emergency Medicine departments, Institute of Medicine and respective institutions prior to the data collection. The participants were recruited from patients admitted with COPD (study group) and apparently healthy people basically patients' visitors (comparison group) in the United Mission Hospital (105 respondents; COPD/Comparison- 46/59) and Okhaldhunga Community Hospital (93 respondents; COPD/ Comparison- 47/46). Those clients willing to give consent were included in the study and the surveys were administered at that time. For those clients who could not read or write, questions were asked verbally and filled by the trained person or researcher.

\section{Measurements}

The Beck Anxiety Inventory (BAI) and the Beck Depression Inventory (BDI) questionnaire were used to assess the anxiety and depression level of respondents. The BAI was used to measure the severity of anxiety consisting of 21 multiple-choice questions. Each question has graded from 0 to 3 with a score of 3 indicating the greatest severity. BAI has score ranging from 0 to 63 . The total score of $0-7$ indicates minimal anxiety, 8-15 mild anxiety, 16-25 moderate anxiety, and 26-63 severe anxiety. The BDI also consists of 21 multiple-choices questions graded from 0 to 3 , with a score of 3 indicating the greatest severity of depression. BDI has a scores ranging from 0 to 63 . The total score of $0-13$ represents healthy, 14-19 minimal level of depression, 20-28 mild depression, and 29-63 severe depression [12-14].

\section{Statistical analysis}

The data were entered, coded and analyzed by using the Statistical Package for Social Sciences (SPSS) version 16. Baseline demographics and clinical characteristics were compared among the groups using cross tabulation and chi square tests. $P<0.05$ was regarded as statistical significance.

\section{Results \\ Sample}

The total number of respondents was 198 (COPD/comparison group: 93/105). The demographic and clinical characteristics are summarized in Table 1 with the mean age of $58.01+12.11(40-82)$ years. A majority (66.9\%) of the respondents in COPD group had a history of smoking

Table 3 Beck depression inventory score level among the respondents

\begin{tabular}{|c|c|c|c|c|c|c|}
\hline \multirow[t]{2}{*}{ Group } & \multicolumn{5}{|l|}{ Depression scale } & \multirow[t]{2}{*}{$P$ value $^{*}\left(x^{2}\right)$} \\
\hline & Minimal depression & $\begin{array}{l}\text { Mild } \\
\text { depression }\end{array}$ & $\begin{array}{l}\text { Moderate } \\
\text { depression }\end{array}$ & $\begin{array}{l}\text { Severe } \\
\text { depression }\end{array}$ & Total & \\
\hline COPD & $4(4.3 \%)$ & $14(15.1 \%)$ & $41(44.1 \%)$ & $34(36.6 \%)$ & 93 (100\%) & $<0.001$ \\
\hline Control & $71(67.6 \%)$ & $23(21.9 \%)$ & $6(5.7 \%)$ & $5(4.8 \%)$ & 105 (100\%) & \\
\hline Total & 75 (37.9\%) & 37 (18.7\%) & 47 (23.7\%) & 39 (19.7\%) & 198 (100\%) & \\
\hline
\end{tabular}

* Chi square value 
tobacco whereas, in comparison group $41.9 \%$ had a history of smoking tobacco.

\section{Anxiety}

The mean score of anxiety in the COPD group was $23.76 \pm 9.51$ and in the comparison group, it was $8.01 \pm$ 6.83. Among the COPD group, 37 (39.8\%) had a severe anxiety level, meanwhile in comparison group only 3 $(2.9 \%)$ had a severe anxiety level (Table 2 ).

\section{Depression}

The mean score for depression in the COPD group was $27.72 \pm 9.37$ and for the comparison group, the mean score for depression was $11.60 \pm 8.42$. As with the scores for depression, 34 (35.5\%) of COPD group respondents had severe depression whereas it was only $5(4.8 \%)$ among comparison group (Table 3).

\section{Characteristics of anxiety and depression}

Gender, occupation, and number of hospitalization were not correlated with scores of BDI and BAI for both groups. However, the age and level of anxiety were statistically significant within the COPD group $(p=0.03)$ and the comparison group $(p<0.001)$. Similarly, age showed significant association with the level of depression in the COPD group $(p<0.05)$.

Family type and level of anxiety had a significant association with $p=0.02$ (COPD group) and $p=0.001$

Table 4 Association between Beck Anxiety Inventory Score Level and different variables of Respondents

\begin{tabular}{|c|c|c|c|c|c|c|}
\hline \multirow[t]{2}{*}{ Group/Nariables } & \multicolumn{5}{|l|}{ Anxiety scale } & \multirow[t]{2}{*}{$P$ value $\left(X^{2}\right)$} \\
\hline & Minimal anxiety & Mild anxiety & Moderate anxiety & Severe anxiety & Total & \\
\hline COPD Group & & & & & & 0.03 \\
\hline Less than 60 years & $0(0 \%)$ & $2(8.0 \%)$ & $7(28 \%)$ & $16(64.0 \%)$ & $25(100 \%)$ & \\
\hline Above 60 years & $4(5.9 \%)$ & $11(16.2 \%)$ & $32(47.1 \%)$ & $21(20.9 \%)$ & 68 (100\%) & \\
\hline Control Group & & & & & & 0.00 \\
\hline Less than 60 years & 45 (55.6\%) & $30(37.0 \%)$ & $6(7.4 \%)$ & $0(0 \%)$ & $81(100 \%)$ & \\
\hline Above 60 years & $14(58.3 \%)$ & $2(8.3 \%)$ & $5(20.8 \%)$ & $3(12.5 \%)$ & $24(100 \%)$ & \\
\hline COPD Group & & & & & & 0.8 \\
\hline Male & $2(4.9 \%)$ & $7(17.1 \%)$ & 17 (41.5\%) & 15 (36.6\%) & $41(100 \%)$ & \\
\hline Female & $2(3.8 \%)$ & $6(11.5 \%)$ & $22(42.3 \%)$ & $22(42.3 \%)$ & $52(100 \%)$ & \\
\hline Control Group & & & & & & 0.1 \\
\hline Male & $42(53.8 \%)$ & 27 (34.6\%) & $6(7.7 \%)$ & $3(3.8 \%)$ & 78 (100\%) & \\
\hline Female & $17(63.0 \%)$ & $5(18.5 \%)$ & $5(18.5 \%)$ & $0(0 \%)$ & $27(100 \%)$ & \\
\hline COPD Group & & & & & & 0.02 \\
\hline Nuclear family & $0(0 \%)$ & $5(38.5 \%)$ & $6(46.2 \%)$ & $2(15.4 \%)$ & $13(100 \%)$ & \\
\hline Joint family & $4(5.0 \%)$ & $8(10.0 \%)$ & $33(41.2 \%)$ & 35 (43.8\%) & $80(100 \%)$ & \\
\hline Control Group & & & & & & 0.001 \\
\hline Nuclear family & 24 (88.9\%) & $3(11.1 \%)$ & $0(0 \%)$ & $0(0 \%)$ & 27 (100\%) & \\
\hline Joint family & 35 (44.9\%) & $29(37.2 \%)$ & $11(14.1 \%)$ & $3(3.8 \%)$ & 78 (100\%) & \\
\hline COPD Group & & & & & & 0.32 \\
\hline Illiterate & $2(2.6 \%)$ & $10(13.2 \%)$ & $32(42.1 \%)$ & $32(42.1 \%)$ & 76 (100\%) & \\
\hline Literate & $2(11.8 \%)$ & $3(17.6 \%)$ & $7(41.2 \%)$ & $5(29.4 \%)$ & 17 (100\%) & \\
\hline Control Group & & & & & & 0.01 \\
\hline Illiterate & $20(45.5 \%)$ & 13 (29.5\%) & $8(18.2 \%)$ & $3(6.8 \%)$ & 44 (100\%) & \\
\hline Literate & 39 (63.9\%) & 19 (31.1\%) & $3(4.9 \%)$ & $0(0 \%)$ & $61(100 \%)$ & \\
\hline COPD Group & & & & & & 0.1 \\
\hline Smoker & $4(4.5 \%)$ & $11(12.4 \%)$ & 39 (43.8\%) & 35 (39.3\%) & 89 (100\%) & \\
\hline Non smoker & $0(0 \%)$ & $2(50.0 \%)$ & $0(0 \%)$ & $2(50.0 \%)$ & $4(100 \%)$ & \\
\hline Control Group & & & & & & 0.01 \\
\hline Smoker & 23 (52.3\%) & $10(22.7 \%)$ & $8(18.2 \%)$ & $3(6.8 \%)$ & 44 (100\%) & \\
\hline Non smoker & 36 (59.0\%) & 22 (36.1\%) & $3(4.9 \%)$ & $0(0 \%)$ & 61 (100\%) & \\
\hline
\end{tabular}


(comparison group) (Tables 4 and 5). Education level of the respondents showed significant association with the level of depression with $\mathrm{p}=0.001$ (Table 5).

\section{Discussion}

This study aimed to describe the levels of anxiety and depression among COPD patients in comparison to the general population. The study demonstrated that majority of the COPD group reported moderate to severe anxiety and depression in comparison to the general population. Chronic somatic diseases are often associated with psychiatric comorbidities [15]. There is a high prevalence rate of depression and anxiety among patients with asthma and COPD.
Higher prevalence of anxiety and depression are observed among patients with COPD even in a mild stage than the general population [16]. It is estimated that anxiety and depression are six times more prevalent in asthmatics in comparison to the general population however some controversies are there. [17].

A similar study reported that anxiety and depression differed by age group: clinically significant levels of depression and anxiety were more prevalent in patients aged less than 60 years, irrespective of clinical severity of COPD [6]. This result contradicts the present study findings that more respondents with age more than 60 years have moderate to severe level

Table 5 Association between beck depression inventory score level and different variables of respondents

\begin{tabular}{|c|c|c|c|c|c|c|}
\hline \multirow[t]{2}{*}{ Group/Nariables } & \multicolumn{5}{|l|}{ Depression scale } & \multirow[t]{2}{*}{$P$ value $\left(X^{2}\right)$} \\
\hline & Minimal depression & Mild depression & Moderate depression & Severe depression & Total & \\
\hline COPD Group & & & & & & 0.009 \\
\hline Less than 60 years & $0(0 \%)$ & $5(20.0 \%)$ & $5(20.0 \%)$ & $15(60.0 \%)$ & $25(100 \%)$ & \\
\hline Above 60 years & $4(5.9 \%)$ & $9(13.2 \%)$ & 36 (52.9\%) & 19 (27.9\%) & $68(100 \%)$ & \\
\hline Control Group & & & & & & 0.3 \\
\hline Less than 60 years & $56(69.1 \%)$ & $16(19.8 \%)$ & $6(7.4 \%)$ & $3(3.7 \%)$ & $81(100 \%)$ & \\
\hline Above 60 years & $15(62.5 \%)$ & 7 (29.2\%) & $0(0 \%)$ & $2(8.3 \%)$ & $24(100 \%)$ & \\
\hline COPD Group & & & & & & 0.9 \\
\hline Male & $2(4.9 \%)$ & $7(17.1 \%)$ & 18 (43.9\%) & $14(34.1 \%)$ & $41(100 \%)$ & \\
\hline Female & $2(3.8 \%)$ & $7(13.5 \%)$ & $23(44.2 \%)$ & 20 (38.5\%) & $52(100 \%)$ & \\
\hline Control Group & & & & & & 0.06 \\
\hline Male & $56(71.8 \%)$ & $13(16.7 \%)$ & $6(7.7 \%)$ & $3(3.8 \%)$ & $78(100 \%)$ & \\
\hline Female & $15(55.6 \%)$ & $10(37.0 \%)$ & $0(0 \%)$ & $2(7.4 \%)$ & $27(100 \%)$ & \\
\hline COPD Group & & & & & & 0.7 \\
\hline Nuclear family & $0(0 \%)$ & $3(23.1 \%)$ & $5(38.5 \%)$ & $5(38.5 \%)$ & $13(100 \%)$ & \\
\hline Joint family & $4(5.0 \%)$ & $11(13.8 \%)$ & $36(45.0 \%)$ & $29(36.2 \%)$ & $80(100 \%)$ & \\
\hline Control Group & & & & & & 0.1 \\
\hline Nuclear family & $18(66.7 \%)$ & $6(22.2 \%)$ & $0(0 \%)$ & $3(11.1 \%)$ & $27(100 \%)$ & \\
\hline Joint family & $53(67.9 \%)$ & $17(21.8 \%)$ & $6(7.7 \%)$ & $2(2.6 \%)$ & 78 (100\%) & \\
\hline COPD Group & & & & & & 0.34 \\
\hline Illiterate & $2(2.6 \%)$ & $12(15.8 \%)$ & 35 (46.1\%) & 27 (35.5\%) & 76 (100\%) & \\
\hline Literate & $2(11.8 \%)$ & $3(11.8 \%)$ & $6(35.3 \%)$ & $7(41.2 \%)$ & 17 (100\%) & \\
\hline Control Group & & & & & & 0.001 \\
\hline Illiterate & 25 (56.8\%) & $14(31.8 \%)$ & $0(0 \%)$ & $5(11.4 \%)$ & 44 (100\%) & \\
\hline Literate & $46(75.4 \%)$ & 9 (14.8\%) & $6(9.8 \%)$ & $0(0 \%)$ & $61(100 \%)$ & \\
\hline COPD Group & & & & & & 0.06 \\
\hline Smoker & $4(4.5 \%)$ & $14(15.7 \%)$ & 41 (46.1\%) & 30 (33.7\%) & 89 (100\%) & \\
\hline Non smoker & $0(0 \%)$ & $0(0 \%)$ & $0(0 \%)$ & $4(100 \%)$ & $4(100 \%)$ & \\
\hline Control Group & & & & & & 0.001 \\
\hline Smoker & $21(47.7 \%)$ & $18(40.9 \%)$ & $3(6.8 \%)$ & $2(4.5 \%)$ & $44(100 \%)$ & \\
\hline Non smoker & 50 (82.0\%) & $5(8.2 \%)$ & $3(4.9 \%)$ & 3 (4.9\%) & 61 (100\%) & \\
\hline
\end{tabular}


of anxiety and depression than those with age less than 60 years.

The risk factors for increased rates of anxiety and depression include gender, lack of support and having more severe diseases in COPD. In comparison to gender, females have higher rate of anxiety and depression, and the rates of depression are more strongly correlated with severity of the disease than males [16]. Similarly, Di Marcto et al. reported that female gender had a high prevalence of anxiety and depression [18]. In the present study higher number females score moderate to severe in both anxiety and depression scale than males, however there was no statistical significant relation between the scores of anxiety/depression and respondent's socio-demographic and clinical characteristics.

Kunik et al. reported that anxiety and depression in COPD patients in a general practitioner's outpatient clinic were $19 \%$ and $23 \%$ respectively which is very much consistent with the present study findings [19]. These high rates stress the importance of screening and treatment of depression and anxiety in patients with COPD to maintain health and functional status, prevent unnecessary hospitalizations, dropout from pulmonary rehabilitation or poor outcomes from smoking cessation programs.

Treatment for COPD is now aimed at immediately relieving and reducing the impact of symptoms, as well as reducing the risk of future adverse events such as exacerbations. A framework for multi-modal COPD management that matches individualized assessment of the disease to these treatment objectives will better meet each patient's needs [1].

Rates of anxiety and depression are high in COPD patients as it is a chronic condition, which needs regular follow up and treatment. In addition to the increased risk of COPD due to tobacco smoking, people living in remote areas use firewood to cook food and their homes are not well ventilated which causes indoor air pollution and increased risk for development of COPD and recurrent exacerbation. These recurrent attacks leads to increased number of readmission in hospital. Due to the effects of COPD on overall health, most patients are unable to work, may be a huge burden for family members, and may be abandoned.

Pooler reported that managing depression and anxiety starts with an accurate diagnosis. To improve the patient's condition, identification of those who have more permanent and sustained anxiety and depression is necessary, along with developing screening methods and implementing effective management strategies to alleviate the impact of the co-morbidities [20].

COPD with anxiety and depression affects family and society as well as the individual patient. Thus it should be addressed accordingly. Medical as well as psychological management is important in the treatment of COPD, counseling to the patient and family about the smoking cessation, proper clothing, immunization, regular follow up and use of medicine.

\section{Conclusion}

In this study, the BAI and BDI scores for anxiety and depression were significantly higher in patients with COPD compared to a sample from the general population. Assessment and management of anxiety and depression are important as these common co-morbidities can negatively impact treatment compliance, make it difficult to control COPD, and lead to increased morbidity and mortality. Future studies should focus on evaluating the effectiveness of multi-modal approaches to management of anxiety and depression in COPD. Examples include the effectiveness of different types of pharmacologic treatment, cognitive behavior therapy and the collaborative-care model for pulmonary rehabilitation.

\section{Abbreviations \\ BAl: Beck Anxiety Inventory; BDI: Beck Depression Inventory; COPD: Chronic obstructive pulmonary disease; FEV: Forced Expiratory Volume; FVC: Forced Vital Capacity; GOLD: Global Initiative for Chronic Obstructive Pulmonary Disease}

\section{Acknowledgements}

The authors would like to acknowledge all the respondents for their participation and cooperation, the hospital administration and staffs of United Mission Hospital and Okhaldhunga Community Hospital for their great support. The authors greatly acknowledge the help of Deborah Lindell DNP, MSN, RN, CNE, ANEF, Associate Professor of Nursing, Frances Payne Bolton School of Nursing, Case Western Reserve University and Carma Erickson-Hurt DNP, ACHPN in the final language editing of this paper.

\section{Authors' contribution}

NT designed the study. NT, PP and YBT participated in data collection. TS and SG participated in the design of the study and helped to draft the manuscript. NT and MM analyzed the data and wrote up the manuscript. All the authors read and approved the final manuscript.

Funding

The study has not got any kind of funding.

\section{Availability of data and materials}

The data sets used and analyzed during the current study are available from the corresponding author on reasonable request.

\section{Ethics approval and consent to participate}

Ethical clearance and permission was taken from ethical review board of the General Practice and Emergency Medicine department, Institute of Medicine and United Mission Hospital, Palpa and Okhaldhunga Community Hospital, Okhaldhunga prior to the data collection. Written informed consent was obtained from the respondents before data collection.

Consent for publication

Not applicable.

Competing interests

The authors declare that they have no competing interests. 


\section{Publisher's Note}

Springer Nature remains neutral with regard to jurisdictional claims in published maps and institutional affiliations.

\section{Author details}

'Department of Gynecological Oncology, Second Clinical College of Wuhan University, Zhongnan Hospital, Wuhan, Hubei, China. ${ }^{2}$ Department of General Practice and Emergency Medicine, Karnali Academy of Health Sciences, Jumla, Nepal. ${ }^{3}$ Second Clinical College of Wuhan University, Hope School of Nursing, Wuhan, Hubei, China. ${ }^{4}$ Department of General Practice and Emergency Medicine, Maharajgunj Medical Campus, Tribhuwan University Teaching Hospital, Kathmandu, Nepal. ${ }^{5}$ Department of General Practice and Emergency Medicine, Patan Academy of Health Sciences, Lalitpur, Nepal. ${ }^{6}$ Department of Medicine, United Mission Hospital, Palpa, Nepal. 'Department of General Practice, Okhaldhunga Community Hospital, Okhaldhunga, Nepal.

Received: 2 May 2017 Accepted: 20 November 2017

Published online: 12 December 2017

\section{References}

1. Global Initiative for Chronic Obstructive Lung Disease. Global strategy for the diagnosis, management, and prevention of chronic obstructive pulmonary disease GOLD executive summary. 2017. Available from: www. goldcopd.org

2. World Health Organization. Noncommunicable diseases in the South-East Asia region. 2011 [cited 2017 Apr 29]. Available from: http://www.searo.who. int/nepal/mediacentre/2011_non_communicable_diseases_in_the_south_ east_asia_region.pdf?ua=1

3. Kasper DL, Hauser SL, Jameson LJ, Fauci AS, Longo DL, Joseph L. Harrison's principles of internal medicine. 19th ed. Newyork: McGraw-Hill Medical; 2015 [cited 2017 Apr 29]. Available from: http://www.harrisonsim.com/

4. Ansari M, Rao BS, Koju R, Shakya R. Impact of pharmaceutical intervention on inhalation technique. KATHMANDU Univ. J Sci Eng Technol. 2005 [cited 2017 Mar 29]; Available from: http://www.ku.edu.np/kuset/aej/mukhtar.pdf

5. Pandey MR. Domestic smoke pollution and chronic bronchitis in a rural community of the hill region of Nepal. Thorax. 1984;39:337-339. [cited 2017 Apr 29]. Available from: https://www.ncbi.nlm.nih.gov/pmc/articles/ PMC459798/pdf/thorax00221-0017.pdf

6. Cleland JA, Lee AJ, Hall S. Associations of depression and anxiety with gender, age, health-related quality of life and symptoms in primary care COPD patients. Fam Pract. 2007;24:217-23.

7. Ng T-P, Tan W-C, Cao Z, Ong K-C. Depressive symptoms and chronic obstructive pulmonary disease effect on mortality, hospital readmission, symptom burden, functional status, and quality of life. Arch Intern Med. 2007;167(1):60-7.

8. Robert P, Carson Alan RG. ABC of psychological medicine: depression in medical patients. BMJ. 2002;325:149-52.

9. Maurer J, Rebbapragada V, Borson S, Goldstein R, Kunik ME, Yohannes AM, et al. Anxiety and depression in COPD: current understanding, unanswered questions, and research needs. Chest. 2008 [cited 2017 Apr 29];134. Available from: https:/www.ncbi.nlm.nih.gov/pmc/articles/PMC2849676/ pdf/nihms101564.pdf

10. Risal A, Manandhar K, Linde M, Steiner TJ, Holen A. Anxiety and depression in Nepal: prevalence, comorbidity and associations. BMC Psychiatry. 2016;16: 102. [cited 2017 Apr 19]. Available from: http://bmcpsychiatry biomedcentral.com/articles/10.1186/s12888-016-0810-0.

11. Putman-Casdorph H, McCrone S. Chronic obstructive pulmonary disease, anxiety, and depression: state of the science. Heart Lung. 2009:38:34-47. [cited 2017 Mar 29]. Available from: http://linkinghub.elsevier.com/retrieve/ pii/S0147956308000241

12. Beck AT, Ward CH, Mendelson M, Mock J, Erbaugh J. An inventory for measuring depression. Arch Gen Psychiatry. 1961;4:561-571. [cited 2017 Mar 29]. Available from: http://counsellingresource.com/lib/wp-content/ managed-media/Beck_AT_1961.pdf

13. Groth-Marnat G. Handbook of Psycholgical assessment. 4th ed. Hoboken, New Jersey: John Wiley \& SOns, Inc; 2003

14. Beck AT, Epstein N, Brown G, Steer RA, others. An inventory for measuring clinical anxiety: psychometric properties. J Consult Clin Psychol. 1988;56: 893-897. [cited 2017 Mar 29]. Available from: http://doi.apa.org/getdoi. cfm?doi=10.1037/0022-006X.56.6.893
15. Wittchen HU, Jacobi F, Rehm J, Gustavsson A, Svensson M, Jonsson B, et al. The size and burden of mental disorders and other disorders of the brain in Europe 2010. Eur Neuropsychopharmacol. 2011;21:655-679. [cited 2017 Apr 29]. Available from: http://ac.els-cdn.com/S0924977X11001726/1-s2.0S0924977X11001726-main.pdf?_tid=fa7b1c88-2cfc-11e7-9a7800000aacb360\&acdnat=1493485250_9514d102559eca7e3d4439100951f748

16. Pumar Ml, Gray CR, Walsh JR, et al. Anxiety and depression - important psychological comorbidities of COPD. J Thorac Dis. 2014;6:1615-31.

17. Asnaashari AMH, Talaei A, Haghighi MB. Evaluation of psychological status in patients with asthma and COPD. Iran J Allergy Asthma Immunol. 2012;11: 65-71. [cited 2017 Apr 20]. Available from: http://ijaai.tums.ac.ir/index.php/ ijaai/article/view/332

18. Di Marco F, Verga M, Reggente M, Maria Casanova F, Santus P, Blasi F, et al. Anxiety and depression in COPD patients: the roles of gender and disease severity. Respir. Med. 2006:100:1767-1774. [cited 2017 Mar 29]. Available from: http://www.resmedjournal.com/article/S0954-6111(06)00060-6/pdf

19. Kunik ME, Roundy K, Veazey C, Souchek J, Richardson P, Wray NP, et al. Surprisingly high prevalence of anxiety and depression in chronic breathing disorders. Chest. 2005;127:1205-1211. [cited 2017 Mar 29]. Available from: http://linkinghub.elsevier.com/retrieve/pii/S0012369215344688

20. Pooler A, Beech R. Examining the relationship between anxiety and depression and exacerbations of COPD which result in hospital admission: a systematic review. Int J Chron Obstruct Pulmon Dis. 2014;9:315-330. [cited 2017 Apr 20]. Available from: https://www.dovepress.com/examining-therelationship-between-anxiety-and-depression-and-exacerba-peerreviewedfulltext-article-COPD.

\section{Submit your next manuscript to BioMed Central and we will help you at every step:}

- We accept pre-submission inquiries

- Our selector tool helps you to find the most relevant journal

- We provide round the clock customer support

- Convenient online submission

- Thorough peer review

- Inclusion in PubMed and all major indexing services

- Maximum visibility for your research

Submit your manuscript at www.biomedcentral.com/submit
Biomed Central 